\title{
A Model Proposal for the Evaluation of Chemistry Education in the Context of Learning Environment
}

\author{
Mehmet Yüksel \\ TUSAŞ Kazan Vocational School, Gazi University, Ankara, Turkey. \\ Email:yukselmehmet@gazi.edu.tr
}

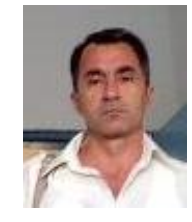

\section{Abstract}

The aim of this study was conducted to evaluate chemistry education in the context of the elements that form the learning environment. The weights of learning environment components were determined by Analytic Hierarchy Process. The significance levels of learning environment dimensions were also calculated. According to the findings of the study, the order of the relative weights of personal interest was found as the highest weighted component. Among the components of the learning environment, the second-order weight is competition, participation in the third place, teacher support in the fourth and innovation in the last component. In addition, the global weights of sub-component was calculated. The evaluations study was conducted to evaluate the 9th grade chemistry course learning environment based on the opinion of the teacher who works as the head of chemistry course in a high school in Ankara were indicated that $61.8 \%$ of the chemistry course in the research has a medium learning level.

Keywords: Learning environment, Chemistry course, Analytic hierarchy process.

Citation | Mehmet Yüksel (2019). A Model Proposal for the Evaluation of Chemistry Education in the Context of Learning Environment. Asian Journal of Education and Training, 5(3): 488494.

History:

Received: 28 June 2019

Revised: 5 August 2019

Accepted: 13 September 2019

Published: 11 October 2019

Licensed: This work is licensed under a Creative Commons

Attribution 3.0 License (cc))

Publisher: Asian Online Journal Publishing Group
Funding: This study received no specific financial support.

Competing Interests: The author declares that there are no conflicts of interests regarding the publication of this paper.

Transparency: The author confirms that the manuscript is an honest, accurate, and transparent account of the study was reported; that no vital features of the study have been omitted; and that any discrepancies from the study as planned have been explained.

Ethical: This study follows all ethical practices during writing.

\section{Contents}

1. Introduction

3. Results

491

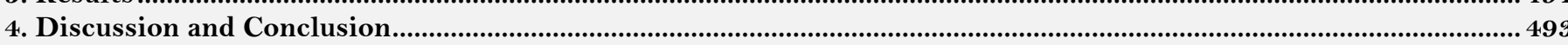

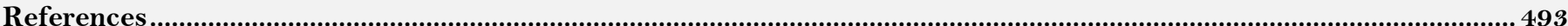




\section{Contribution of this paper to the literature}

This study contributes to the existing literature by investigating the learning environment for a chemistry course in high school based on chemistry teacher's opinions.

\section{Introduction}

There are many factors that determine the sustainability and development of human species in the historical process (Gungor, 1998; Özüşen and Yıldız, 2012). However, when the gains and accumulations in human history are taken into consideration, education which is a product of human and invention (Bircan, 2018) has a primary role. As a matter of fact, when we look at it from the macro perspective, it is seen that education is the main tool used by mankind to maintain its existence and improve the quality of life on our planet. As a living species, human beings have used the method of education to produce and acquire what was given to them by nature. Education has been the basic behavior that distinguishes human beings from other living things. The production, protection, reproduction and use of the information transferred from the prehistoric man to the present has been possible through education. The main reason why education is functional for human beings is due to the suitability of human nature to education. In other words, when compared to other living things on the planet we live in, the educable potential of the unique superiority of human beings is more (Şişman, 2007; Bircan, 2018). With the discovery of the qualification of being educable, the sustainability of human beings in the historical process has become more powerful and developmental than other creatures. It shows that the functionalities of education and the acquisitions of human beings are possible with the learning phenomenon of various cultures and civilizations formed in the historical process.

In the literature, it is stated that one of the explanatory variables is the learning environment when the scientific studies aimed at explaining the learning phenomenon and realizing the learning are examined (Demirtas et al., 2015). The learning environment defines the choice of teaching method that will enable learning to take place, the design of the appropriate teaching environment, the execution of the planned activities and the evaluation of the whole process (Keser and Ali, 2002). The specificity of the learning environment principles and rules, the criteria of reward and encouragement, the ability of the teacher, the behavior of participation in the lesson, norms, physical environment characteristics, as well as the relationship pattern between stakeholders, in other words, between managers, students, teachers, school, and family. These characteristics affect students' academic knowledge, attitudes and behaviors in different ways (Kose and Kucukoglu, 2009). The learning environment has an impact on the achievement of the intended education, in other words, on the realization of learning effectiveness. As a matter of fact, there is the opinion that learning is not dependent only on the learner and the teacher in the constructivism philosophy which forms the basis of the Turkish education system today. At the same time, learning environments are decisive in the realization of learning (Giallousi et al., 2010; Demirtas et al., 2015). From this point of view, the issue of learning environments has been the subject of numerous studies in terms of various contexts and variables.

In the review of literature, it was seen that learning environment was the subject of studies in the contexts of students, teachers, teaching program, classroom environment, and school environment (Telli et al., 2009; Den Brok et al., 2010; Tuncer et al., 2012; Schreglman and Mengi, 2013; Demirtas et al., 2015; Özerem and Akkoyunlu, 2015; Tunca, 2015; Aydogdu and AY, 2016). The studies on the learning environment were conducted with a descriptive and relational approach. Although the studies in the literature have provided important findings and information on the learning environment and the effectiveness of education, there are some issues that may be the subject of research. One is how to assess the appropriateness of the learning environment for the intended education with a holistic approach. A systematic evaluation of the level of appropriateness of the learning environment to the targeted education is a necessary study in order to determine the effectiveness of the given education objectively. However, it can be stated that the model to allow the evaluation of the education given in the context of learning environment should contain some characteristics. The first is that the learning environment assessment model needs to be inclusive and holistic because the nature of the learning environment is composed of many different components with various natures. Therefore, the model for assessing the learning environment should allow for a multi-dimensional assessment. As a matter of fact, in the literature review, it is seen that the solution and evaluation of the problems which have a multi-dimensional structure were made with multi criteria approaches (Vaidya and Kumar, 2006; Melon et al., 2008). Another issue that should be mentioned is that the learning environment assessment model should be capable of providing data and information on the level of acceptability of education in terms of effectiveness. However, a model with these characteristics may be able to evaluate the education given in the context of learning environment. Considering the above-mentioned issues in the assessment of the learning environment is important for the realization of the effectiveness of education. As Küçüközer et al. (2012) stated, it is important to create an environment suitable for its purpose, analyze the learning environment with appropriate methods, identify the deficiencies and improve the learning environment.

Based on the above considerations, the main purpose of this study is to provide an analytical model for evaluating chemistry education in the context of the elements that make up the learning environment. The first of the sub-objectives of the study is to determine the importance levels of the elements that constitute the learning environment within the learning environment with a holistic approach that takes other elements into consideration. The second sub-objective of the study is to evaluate chemistry education according to the elements of the learning environment in the opinion of the teacher who works as the head of the chemistry course in a high school in Ankara.

\section{Method}

In this study, the content of 9th grade chemistry course constitutes the scope of the study in relation to the evaluation of chemistry education on the basis of learning environment. The analysis unit of the study is a 9th grade chemistry course learning environment in a public school in Ankara. In the study, the analysis of the 
learning environment was structured with a multi-criteria model. Approaches of multi-criterion studies in the literature were taken as basis in the formation of the model for the evaluation of chemistry education according to the learning environment (Yüksel and Dağdeviren, 2006; Yüksel and Geban, 2015).

The assessment of chemistry education in the context of learning environment was carried out with the Analytical Hierarchy Process (AHP). The reason for using AHP (Saaty, 1980) technique in this study is its suitability to the purpose and characteristics of the problem. Since the assessment of the learning environment requires a multidimensional analysis and evaluation, AHP, which has a multidimensional characteristic, was used in the study. AHP was developed by Saaty (1980) as a multi-criteria decision making technique. AHP technique is a multi-criteria decision making approach with mathematical axioms (Saaty, 1980; 1986; 1991; 1994).

It is possible to solve the problems that are multidimensional and hierarchical in nature by AHP technique. Therefore, in order to solve a problem in AHP technique, firstly the hierarchical model which expresses the structure of the problem should be determined. For this purpose, the components that constitute the nature of the problem are determined first. Components and sub-components or alternatives are categorized at hierarchical levels to form a model (Saaty, 1990). Another process in AHP technique is to make binary comparisons according to component and subcomponents in the model representing the problem. The relative weights of each component can be calculated by means of matrices created as a result of binary comparisons in AHP. Comparison of the two components 'i.' and 'j.' in AHP is defined as $a_{\mathrm{ijj}}$. In contrast, the comparison of the 'j.' component with the 'i.' component is represented by the term $\mathrm{a}_{\mathrm{ji}}$. Another feature is that the term aij corresponds to $\mathrm{a}_{\mathrm{ji}}\left(\mathrm{a}_{\mathrm{ji}}=1 / \mathrm{aij}\right)$. However, $\mathrm{a}_{\mathrm{ij}}$ is $\neq \mathrm{O}$ (Vashishtha and Ramachandran, 2006). In AHP, the scale given in Table 1 (Saaty, 1980) is used for binary comparisons (Yüksel and Geban, 2018). The reason for using AHP (Saaty, 1980) technique in this study is its suitability to the purpose and characteristics of the problem.

Table-1. Importance levels in binary comparisons

\begin{tabular}{c|l|l}
\hline $\mathbf{a}_{\mathbf{i j}}$ & Definition & Explanation \\
\hline 1 & Equal importance & Two activities contribute equally to the objective \\
\hline 3 & Weak importance & An activity is favored very slightly over another \\
\hline 5 & Strong importance & An activity is favored strongly over another \\
\hline 7 & Very strong or demonstrated importance & An activity is favored very strongly over another \\
\hline 9 & Extreme importance & $\begin{array}{l}\text { The evidence favoring one activity over another is } \\
\text { of the highest possible order of affirmation }\end{array}$ \\
\hline $2,4,6,8$ & Intermediate values & Used when necessary \\
\hline
\end{tabular}

In AHP, the matrices determined as a result of binary comparisons of the elements contained in the model are square (nxn) matrices. In each binary comparison matrix, a size-dependent comparison is performed. The weight of one element of the binary comparison matrix is calculated by the equation $\left(A-\lambda_{\max } \mathrm{I}\right) \mathrm{W}=0$. In the equation, "A" refers to matrix and "W" refers to eigenvector. " $\lambda_{\max }$ " term, on the other hand, represents "A"s eigenvalue (Chou et al., 2004).

Another feature of AHP is the ability to calculate the consistency of comparisons. This feature predicts that the comparisons will be consistent. Consistency is based on the logical consistency of comparisons. For this, inconsistency levels of matrices are calculated. To do this, consistency index (C.I) is calculated first. The consistency index is obtained by the equation $\left(\lambda_{\max }-n\right) /(n-1)$. In this equation, " $n$ " refers to the dimension of binary comparison matrix. Following the calculation of consistency index, the inconsistency ratio (IR) is obtained by (C.I)/(R.I) (Saaty, 1977; Ananda and Herath, 2003; Herath, 2004). The random index (R.I) value in the equation differs according to the size of the binary comparison matrix. If the calculated inconsistency value is less than 0.10 , it means that significant comparisons are made (Saaty, 1994; Cheng and Li, 2007). Otherwise, as there is inconsistency in binary comparisons, binary comparisons are performed again. When the elements $(n)$ of the comparison matrices are large $(n \geq 5)$, the calculations are performed with the Expert Choice (2000) decisionmaking program.

There are many scales developed in the literature to evaluate learning environments (Keser and Ali, 2002; Kose and Kucukoglu, 2009; Giallousi et al., 2010; Küçüközer et al., 2012; Valdez, 2012; Schreglman and Mengi, 2013). In this study, the scale developed by Giallousi et al. (2010) was used. The main reason for this is that the scale was prepared for chemistry course. The scale consists of a total of 28 items collected under five dimensions.

The dimensions and items related to the learning environment are:

2.1. Innovation (IN)

Trying out new ideas in the classroom (IN1).

Using new and different teaching methods in the classroom (IN2).

Teacher's liking students who try original projects (IN3).

Teacher's producing new and interesting activities for students to do (IN4).

Teacher's giving lecture notes in chemistry class (IN5).

\subsection{Personal Relevance (PR)}

Learning about the world outside the school (PI1).

New learning beginnings are problems with the world outside the school (PI2).

Learning how chemistry is a part of life outside the school (PI3).

Better understanding of the environment outside the school (PI4).

Learning interesting things about the world outside the school (PI5).

Being stressful when competing with schoolmates (CP1). 
Making huge efforts to get the highest grades $(\mathrm{CP} 2)$.

Chemistry grades being very important for students (CP3).

Taking notes of classmates into consideration $(\mathrm{CP} 4)$.

Working hard to get high grades (CP5).

The class's sometimes being divided into competing groups (CP6).

\subsection{Participation (PT)}

Discussion of ideas in the classroom (PT1).

Speaking of ideas during class discussion (PT2).

Teacher's asking questions (PT3).

Using ideas and suggestions in the class discussion process (PT4).

Asking questions to the teacher (PT5).

Explaining their thoughts to other students (PT6).

Discussion of the solution of the problems related to mathematical calculations with the student (PT7).

Asking students how to solve mathematical problems (PT8).

\subsection{Teacher Support (TS)}

Teacher's effort to help the student (TS1).

Teacher's consideration of the student's views (TS2).

Teacher's help in case of problems during study (TS3).

Teacher's talking with the student (TS4).

Teacher's interest in student's problems (TS5).

Teacher's questions help the student understand (TS6).

Data for the study were gathered in two ways. The first one was the data provided by the expert group in determining the relative weight of the learning environment dimensions and sub-dimensions covered by the Analytical Hierarchy Process model proposed in the study. The opinions of the expert group were used in the binary comparisons of the components and sub-components in the AHP model. The expert group made the evaluations with the scale (Saaty, 1980; Yüksel and Geban, 2018) given in Table 1. The expert group of the research consisted of two experienced chemistry teachers who gave 9th grade chemistry lessons and the author of the study. The second data required for the study was obtained from the answers given to a scale consisting of 28 items for the 9th grade chemistry course learning environment of an experienced chemistry teacher working as the head of chemistry course in a high school in Ankara. In this study, the evaluations of the experienced chemistry teacher who worked as the head of the chemistry course for the learning environment items were made with the scale given in Table 2 (Yüksel, 2012).

Table-2. Evaluation scale.

\begin{tabular}{c|c}
\multicolumn{2}{c}{ Table-2. Evaluation scale. } \\
\hline Current status level & Level value \\
\hline Certainly acceptable $(\mathrm{CA})$ & 1.00 \\
\hline Acceptable $(\mathrm{AC})$ & 0.75 \\
\hline Satisfactory(SA) & 0.50 \\
\hline Not satisfactory $(\mathrm{NS})$ & 0.25 \\
\hline Certainly unacceptable $(\mathrm{CU})$ & 0.00 \\
\hline
\end{tabular}

\section{Results}

In the study, the weights of learning environment components were determined by Analytic Hierarchy Process. In addition, the significance levels of the 28 learning environment sub-dimensions were also calculated. The consistency levels of the pairwise comparisons, which are the basis for the calculation of the weights of the dimensions and the sub-dimensions, were calculated and the consistency levels of the paired comparisons in the study were found to be acceptable.

In the study, the matrix and the results for determining the weights of the learning environment components were given in Table 3. When the weights of learning environment components were examined, personal interest was found as the highest weighted component. Among the components of the learning environment, the secondorder weight is competition, participation in the third place, teacher support in the fourth and innovation in the last component. Consistency ratio of the components of the learning environment was found to be acceptable (0.08).

Table-3. Components of learning environment.

\begin{tabular}{c|c|c|c|c|c|c}
\hline Components & IN & PR & CP & PT & TS & Local weight \\
\hline Innovation (IN) & 1 & $1 / 5$ & $1 / 5$ & $1 / 5$ & $1 / 3$ & 0.046 \\
\hline Personal relevance (PR) & & 1 & 3 & 3 & 5 & 0.444 \\
\hline Competitiveness (CP) & & & 1 & 3 & 3 & 0.260 \\
\hline Participation (PT) & & & & 1 & 3 & 0.166 \\
\hline Teacher support (TS) & & & & & 1 & 0.085 \\
\hline CR: 0.08
\end{tabular}

Comparisons and calculated weights of the learning environment sub-components were presented in Table 4-8. The relative weights and consistency ratios $(\mathrm{CR})$ of the subcomponents were given in these tables. 
Table-4. Innovation

\begin{tabular}{l|c|c|c|c|c|c}
\hline Components & IN1 & IN2 & IN3 & IN4 & IN5 & Local weight \\
\hline Trying out new ideas in the classroom (IN1) & 1 & 2 & 3 & 2 & 5 & 0.362 \\
\hline $\begin{array}{l}\text { Using new and different teaching methods in the } \\
\text { classroom (IN2) }\end{array}$ & & 1 & 3 & 3 & 5 & 0.304 \\
\hline Teacher's liking students who try original projects (IN3) & & & 1 & $1 / 3$ & 3 & 0.104 \\
\hline $\begin{array}{l}\text { Teacher's producing new and interesting activities for } \\
\text { students to do (IN4) }\end{array}$ & & & 1 & 3 & 0.177 \\
\hline Teacher's giving lecture notes in chemistry class (IN5) & & & & & 1 & 0.053 \\
\hline
\end{tabular}

giving lecture notes in chemistry class (IN5)

Table-5. Personal relevance

\begin{tabular}{|c|c|c|c|c|c|c|}
\hline Components & PR1 & PR2 & PR3 & PR4 & PR5 & Local weight \\
\hline Learning about the world outside the school (PI1) & 1 & 1 & $1 / 3$ & $1 / 5$ & $1 / 3$ & 0.077 \\
\hline $\begin{array}{l}\text { New learning beginnings are problems with the } \\
\text { world outside the school (PI } 2 \text { ) }\end{array}$ & & 1 & 1 & $1 / 3$ & $1 / 5$ & 0.091 \\
\hline $\begin{array}{l}\text { Learning how chemistry is a part of life outside } \\
\text { the school (PI3) }\end{array}$ & & & 1 & $1 / 3$ & $1 / 5$ & 0.120 \\
\hline $\begin{array}{l}\text { Better understanding of the environment outside } \\
\text { the school (PI } 4 \text { ) }\end{array}$ & & & & 1 & 1 & 0.331 \\
\hline $\begin{array}{l}\text { Learning interesting things about the world } \\
\text { outside the school (PI5) }\end{array}$ & & & & & 1 & 0.382 \\
\hline
\end{tabular}
CR: 0.05 .

Table-6. Competitiveness.

\begin{tabular}{|c|c|c|c|c|c|c|c|}
\hline Components & CP1 & $\mathrm{CP2}$ & CP3 & CP4 & CP5 & CP6 & Local weight \\
\hline $\begin{array}{l}\text { Being stressful when competing with } \\
\text { schoolmates }(\mathrm{CP} 1)\end{array}$ & 1 & 5 & 3 & 5 & 5 & 7 & 0.452 \\
\hline $\begin{array}{l}\text { Making huge efforts to get the highest } \\
\text { grades (CP2) }\end{array}$ & & 1 & 3 & 3 & 3 & 5 & 0.211 \\
\hline $\begin{array}{l}\text { chemistry grades being very important for } \\
\text { students (CP } 3)\end{array}$ & & & 1 & 3 & 3 & 5 & 0.152 \\
\hline $\begin{array}{l}\text { Taking notes of classmates into } \\
\text { consideration }(\mathrm{CP} 4)\end{array}$ & & & & 1 & 3 & 3 & 0.090 \\
\hline Working hard to get high grades (CP5) & & & & & 1 & 3 & 0.062 \\
\hline $\begin{array}{l}\text { The class's sometimes being divided into } \\
\text { competing groups }(\mathrm{CP} 6)\end{array}$ & & & & & & 1 & 0.034 \\
\hline
\end{tabular}
CR: 0.09.

Table-7. Participation

\begin{tabular}{l|c|c|c|c|c|c|c|c|c}
\hline Components & PT1 & PT2 & PT3 & PT4 & PT5 & PT6 & PT7 & PT8 & Local weight \\
\hline $\begin{array}{l}\text { Discussion of ideas in the classroom } \\
\text { (PT1) }\end{array}$ & 1 & 1 & 5 & 1 & 5 & 1 & 5 & 5 & 0.198 \\
\hline $\begin{array}{l}\text { Speaking of ideas during class } \\
\text { discussion (PT2) }\end{array}$ & 1 & 5 & 1 & 5 & 1 & 5 & 5 & 0.198 \\
\hline Teacher's asking questions (PT3) & & & 1 & $1 / 5$ & $1 / 5$ & $1 / 5$ & 3 & 3 & 0.045 \\
\hline $\begin{array}{l}\text { Using ideas and suggestions in the } \\
\text { class discussion process (PT4) }\end{array}$ & & & 1 & 5 & $1 / 3$ & 5 & 5 & 0.181 \\
\hline $\begin{array}{l}\text { Asking questions to the teacher } \\
\text { (PT5) }\end{array}$ & & & & 1 & $1 / 5$ & 5 & 5 & 0.087 \\
\hline $\begin{array}{l}\text { Explaining their thoughts to other } \\
\text { students (PT6) }\end{array}$ & & & & & 1 & 5 & 3 & 0.231 \\
\hline $\begin{array}{l}\text { Discussion of the solution of the } \\
\text { problems related to mathematical } \\
\text { calculations with the student (PT7) }\end{array}$ & & & & & & & & 1 & 0.028 \\
\hline $\begin{array}{l}\text { Asking students how to solve } \\
\text { mathematical problems (PT8) }\end{array}$ & & & & & & & 1 & 0.032 \\
\hline $\begin{array}{l}\text { CR:0.10 } \\
\end{array}$
\end{tabular}

Table-8. Teacher support

\begin{tabular}{|c|c|c|c|c|c|c|c|}
\hline Components & TS1 & TS2 & TS3 & TS4 & TS5 & TS6 & Local weight \\
\hline Teacher's effort to help the student (TS1) & 1 & $1 / 5$ & $1 / 3$ & $1 / 3$ & $1 / 3$ & $1 / 3$ & 0.047 \\
\hline $\begin{array}{l}\text { Teacher's consideration of the student's views } \\
\text { (TS2) }\end{array}$ & & 1 & 5 & 5 & 3 & 3 & 0.438 \\
\hline $\begin{array}{l}\text { Teacher's help in case of problems during study } \\
\text { (TS3) }\end{array}$ & & & 1 & 5 & 3 & 3 & 0.229 \\
\hline Teacher's talking with the student (TS4) & & & & 1 & 1 & 1 & 0.086 \\
\hline Teacher's interest in student's problems (TS5) & & & & & 1 & 1 & 0.100 \\
\hline $\begin{array}{l}\text { Teacher's questions help the student understand } \\
\text { (TS6) }\end{array}$ & & & & & & 1 & 0.100 \\
\hline
\end{tabular}

In the study, the global weights of subcomponents calculated as a result of binary comparisons are given in the fourth column of Table 9. The evaluations made by the head of the chemistry class in the school, where the study was conducted to evaluate the 9th grade chemistry course learning environment, were indicated in the fifth and 
sixth columns of Table 9. In the fifth column, the current status level of the learning environment sub-component and in the sixth column were given the corresponding numerical value. In the last column of Table 9, the evaluation level of each learning environment sub-component was calculated. In the last line of Table 9 is the general level of assessment of the chemistry course within the study. According to the findings of this study, the calculated value is 0.618 . It can be said that this value indicates that $61.8 \%$ of the chemistry course in the research has a medium learning level. As a matter of fact, according to the model proposed in this study, the maximum value that can be taken in the assessment of learning environment is 1.00 and the minimum value is 0 . Therefore, as the result of the evaluation approaches 1.00 , it is understood that there is an acceptable learning environment.

Table-9. Evaluation of chemistry education according to learning environment.

\begin{tabular}{|c|c|c|c|c|c|c|}
\hline $\begin{array}{l}\text { Components and weights of } \\
\text { learning environment }\end{array}$ & Subcomponents & Local weights & $\begin{array}{c}\text { General } \\
\text { weights } \\
(\mathrm{GW})\end{array}$ & $\begin{array}{l}\text { Level } \\
\text { status }\end{array}$ & $\begin{array}{c}\text { Value } \\
(\mathrm{V})\end{array}$ & $\begin{array}{c}\text { Evaluation } \\
\text { level } \\
(\mathrm{GW} \times \mathrm{V})\end{array}$ \\
\hline Innovation (IN) & IN1 & 0.362 & 0.017 & $\mathrm{AC}$ & 0.75 & 0.013 \\
\hline \multirow[t]{4}{*}{0.046} & $\mathrm{IN} 2$ & 0.304 & 0.014 & $\mathrm{AC}$ & 0.75 & 0.011 \\
\hline & IN3 & 0.104 & 0.005 & $\mathrm{CA}$ & 1.00 & 0.005 \\
\hline & IN4 & 0.177 & 0.008 & $\mathrm{AC}$ & 0.75 & 0.006 \\
\hline & IN5 & 0.053 & 0.002 & $\mathrm{CA}$ & 1.00 & 0.002 \\
\hline Personal relevance $(\mathrm{PR})$ & PR1 & 0.077 & 0.034 & $\mathrm{AC}$ & 0.75 & 0.026 \\
\hline \multirow{4}{*}{0.444} & $\mathrm{PR} 2$ & 0.091 & 0.040 & $\mathrm{SA}$ & 0.50 & 0.020 \\
\hline & PR3 & 0.120 & 0.053 & SA & 0.50 & 0.027 \\
\hline & PR4 & 0.331 & 0.147 & $\mathrm{NS}$ & 0.25 & 0.037 \\
\hline & PR5 & 0.382 & 0.169 & SA & 0.50 & 0.085 \\
\hline Competitiveness (CP) & $\mathrm{CP} 1$ & 0.452 & 0.117 & $\mathrm{CA}$ & 1.00 & 0.117 \\
\hline \multirow[t]{5}{*}{0.260} & $\mathrm{CP} 2$ & 0.211 & 0.055 & $\mathrm{AC}$ & 0.75 & 0.041 \\
\hline & $\mathrm{CP} 3$ & 0.152 & 0.040 & $\mathrm{AC}$ & 0.75 & 0.030 \\
\hline & $\mathrm{CP} 4$ & 0.090 & 0.023 & $\mathrm{ACS}$ & 0.75 & 0.017 \\
\hline & $\mathrm{CP} 5$ & 0.062 & 0.016 & $\mathrm{SA}$ & 0.50 & 0.008 \\
\hline & $\mathrm{CP} 6$ & 0.034 & 0.009 & $\mathrm{CU}$ & 0.00 & 0.000 \\
\hline Participation (PT) & PT1 & 0.198 & 0.033 & $\mathrm{AC}$ & 0.75 & 0.025 \\
\hline \multirow[t]{7}{*}{0.166} & $\mathrm{PT} 2$ & 0.198 & 0.033 & $\mathrm{AC}$ & 0.75 & 0.025 \\
\hline & PT3 & 0.045 & 0.007 & $\mathrm{CA}$ & 1.00 & 0.007 \\
\hline & $\mathrm{PT} 4$ & 0.181 & 0.030 & SA & 0.50 & 0.015 \\
\hline & PT5 & 0.087 & 0.014 & $\mathrm{CA}$ & 1.00 & 0.014 \\
\hline & PT6 & 0.231 & 0.038 & NS & 0.25 & 0.010 \\
\hline & PT7 & 0.028 & 0.005 & $\mathrm{CA}$ & 1.00 & 0.005 \\
\hline & PT8 & 0.032 & 0.005 & $\mathrm{CA}$ & 1.00 & 0.005 \\
\hline Teacher support (TS) & $\mathrm{TS} 1$ & 0.047 & 0.004 & CA & 1.00 & 0.004 \\
\hline \multirow[t]{6}{*}{0.085} & $\mathrm{TS} 2$ & 0.438 & 0.037 & $\mathrm{AC}$ & 0.75 & 0.028 \\
\hline & TS3 & 0.229 & 0.019 & $\mathrm{CA}$ & 1.00 & 0.019 \\
\hline & TS4 & 0.086 & 0.007 & $\mathrm{AC}$ & 0.75 & 0.005 \\
\hline & TS5 & 0.100 & 0.008 & $\mathrm{CA}$ & 1.00 & 0.008 \\
\hline & TS6 & 0.100 & 0.008 & $\mathrm{AC}$ & 0.75 & 0.006 \\
\hline & \multicolumn{5}{|l|}{ Total } & 0.618 \\
\hline
\end{tabular}

\section{Discussion and Conclusion}

According to the results of the study, it was seen that the learning environment for a chemistry course can be evaluated in detail with the proposed analytical model. In the study, the proposed model for the assessment of the learning environment was found to be functional and gave meaningful results. As a matter of fact, it was observed that the pattern of a learning environment can be formed with the model proposed and evaluated with a mathematical approach on the basis of the pattern. With the methodically proposed model, it can be said that it is possible to evaluate the learning environments related to courses in other fields of science. However, the results obtained as a result of the analysis of the data produced within the scope of this study are limited to the class in the study. It is an expected result that different research data and application results of the model may differ. Therefore, it is important to consider this limitation in the interpretation of the results of the study. Another aspect is the analysis techniques used by the proposed model. In this study, one of the components and sub-components of the model representing the learning environment is assumed to be independent of each other. But one of the components and sub-components that make up the learning environment may be related to each other. Therefore, this issue needs to be taken into consideration in the creation of a learning environment model. In the following studies, it can be said that studies that take into consideration the relationship between the learning environments between the components or the sub-components can be done with the Analytical Network Process method.

\section{References}

Ananda, J. and G. Herath, 2003. The use of analytic hierarchy process to incorporate stakeholder preferences into regional forest planning. Forest Policy and Economics, 5(1): 13-26.Available at: https://doi.org/10.1016/s1389-9341(02)O0043-6.

Aydogdu, B. and T.S. AY, 2016. Determination of teacher characteristics that support constructivist learning environments. Eurasian Journal of Educational Research, 16(63): 293-310.Available at: https://doi.org/10.14689/ejer.2016.63.17.

Bircan, H.H., 2018. Education and philosophy-natural / human, social and philosophical basis of education. Yüzüncü Yıl University Journal of the Institute of Social Sciences, 40: 157-172.

Cheng, E.W. and H. Li, 2007. Application of ANP in process models: An example of strategic partnering. Building and Environment, 42(1): 278-287.Available at: https://doi.org/10.1016/j.buildenv.2005.07.031.

Chou, Y., C. Lee and J. Chung, 2004. Understanding m-commerce payment systems through the analytic hierarchy process. Journal of Business Research, 57(12): 1423-1430.Available at: https://doi.org/10.1016/s0148-2963(02)00432-0. 
Demirtas, B., O.U.Z. Yahya, L. Uredi and S. Akbasli, 2015. Constructivist learning environments assessment. Bartın University Faculty of Education Journal: Special Issue: 235-245.

Den Brok, P., S. Telli, J. Cakiroglu, R. Taconis and C. Tekkaya, 2010. Learning environment profiles of Turkish secondary biology classrooms. Learning Environments Research, 13(3): 187-204.Available at: https://doi.org/10.1007/s 10984-010-9076-5.

Expert Choice, 2000. Analytical hierarchy process (AHP) software, version, 9.

Giallousi, M., V. Gialamas, N. Spyrellis and E.A. Pavlatou, 2010. Development, validation, and use of a Greek-language questionnaire for assessing learning environments in grade 10 chemistry classes. International Journal of Science and Mathematics Education, 8(4): $761-782$.

Gungor, A., 1998. Reflections of nutrition on human morphology in neolithic period. Ankara University Journal of Language and HistoryGeography, 38(1-2): 367-379.

Herath, G., 2004. Incorporating community objectives in improved wetland management: The use of the analytic hierarchy process. Journal of Environmental Management, 7O(3): 263-273.Available at: https://doi.org/10.1016/j.jenvman.2003.12.011.

Keser, O.F. and R.M. Ali, 2002. Evaluation of integrative learning environments with multiple research approaches. V. National Science and Mathematics Education Congress. (September 16-18) METU. Ankara.

Kose, E. and A. Kucukoglu, 2009. Evaluation of classroom learning environment in education faculties in terms of some variables. Ahi Evran University Journal of the Faculty of Education, 10(3): 61-73.

Küçüközer, H., K. Ad, V. Nilay, A. Leyla and E. Saliha, 2012. Turkish adaptation of constructivist learning environment Survey. Ilkogretim Online, $11(3): 671-688$.

Melon, M.G., P.A. Beltran and M.C.G. Cruz, 2008. An AHP-based evaluation procedure for innovative educational projects: A face-to-face vs. computer-mediated case study. Omega, 36(5): 754-765.Available at: https://doi.org/10.1016/j.omega.2006.01.005.

Özerem, A. and B. Akkoyunlu, 2015. Learning environments designed according to learning styles and its effects on mathematics achievement. Eurasian Journal of Educational Research, 15(61): 61-80.Available at: https://doi.org/10.14689/ejer.2015.61.4.

Özüşen, B. and Z. Yıldız, 2012. History of consumption from the ice age to the first age. Süleyman Demirel University Visionary Journal, $4(7): 1-16$.

Saaty, T.L., 1977. A scaling method for priorities in hierarchical structures. Journal of Mathematical Psychology, 15(3): $234-281$.

Saaty, T.L., 1980. The analytic hierarchy process. New York, USA: McGrawHill International.

Saaty, T.L., 1986. Axiomatic foundation of the analytic hierarchy process. Management Science, 32(7): 841-855.Available at: https://doi.org/10.1287/mnsc.32.7.841.

Saaty, T.L., 1990. How to make a decision: The analytic hierarchy process. European Journal of Operational Research, 48(1): 9-26.Available at: https://doi.org/10.1016/0377-2217(90)90057-i.

Saaty, T.L., 1991. Some mathematical concepts of the analytic hierarchy process. Behaviormetrika, 18(29): 1-9. DOI https://doi.org/10.2333/bhmk.18.29_1.

Saaty, T.L., 1994. How to make a decision: The analytic hierarchy process. Interfaces, 24(6): 19-43.Available at: https://doi.org/10.1287/inte.24.6.19.

Schreglman, S. and F. Mengi, 2013. Constructivist class learning environment perception. Gumushane University Institute of Social Sciences Electronic Journal, 4(7): 160-171.

Şişman, M., 2007. Introduction to education. Ankara: Pegem Publishing.

Telli, S., P. Brok, C. Tekkaya and J. Çakıroğlu, 2009. Turkish students' perceptions of their biology learning environments: The effects of gender and grade level. Asian Journal of Educational Research and Synergy, 1(1): 110-124.

Tunca, N., 2015. The regression level of constructivist learning environment characteristics on classroom environment characteristics supporting critical thinking. Eurasian Journal of Educational Research, 15(60): 181-200.Available at: https://doi.org/10.14689/ejer.2015.60.11.

Tuncer, M., S. Bal, A. Özüt and N. Köse, 2012. Evaluation of several learning environment variables at secondary institutions. Gaziantep University Journal of Social Sciences, $11(1): 85-101$.

Vaidya, O.S. and S. Kumar, 2006. Analytic hierarchy process: An overview of applications. European Journal of Operational Research, 169(1): $1-29$.

Valdez, A., 2012. Assessing mathematics classroom instruction: Observation of learning environments (OLE). Psychology Journal, 9(1): 3543.

Vashishtha, S. and M. Ramachandran, 2006. Multicriteria evaluation of demand side management (DSM) implementation strategies in the Indian power sector. Energy, 31(12): 22 10-2225.Available at: https://doi.org/10.1016/j.energy.2005.10.005.

Yüksel, I., 2012. Developing a multi-criteria decision making model for PESTEL analysis. International Journal of Business and Management, 7(24): 52-66.

Yüksel, İ. and M. Dağdeviren, 2006. An early warning model for determining the risk of misconduct in socio-technical systems. Gazi University Journal of the Faculty of Engineering and Architecture, $21(4):$ 791-799.

Yüksel, M. and Ö. Geban, 2015. Evaluation of teacher performance according to chemistry teacher special field competencies evaluation of teacher performance according to the special area competencies of chemistry teachers. HU Journal of Education, 30(1): $299-312$.

Yüksel, M. and Ö. Geban, 2018. Student performance task assessment using multiple criteria decision making (MCDM) techniques: An application for 9th grade chemistry course. Bartın University Faculty of Education Journal, 7(3): 874-901. 